\title{
Spain in the United Nations: Sixtieth Anniversary
}

\author{
Xavier PONS RAFOLS
}

\begin{abstract}
On the occasion of the sixtieth anniversary of Spain's admission into the United Nations (UN), which took place in 1955 , this article provides a summary of the principal Spanish contributions to this International Organization, especially from the point of view of Public International Law. At the same time, I seek to show how the UN has contributed to Spain's own political, economic and social evolution, and what these sixty years of membership in this Organization have meant for our country, given that the UN expresses the universal aspirations to peace, development and human rights as no other organization does.
\end{abstract}

Keywords: United Nations - Spain

\section{INTRODUCTION}

As of 2015, Spain has been in the UN for sixty years, which makes for an excellent occasion for composing - albeit in summary form - an evaluation of Spain's incorporation into this international organization par excellence. This is a "bottom line" that has to be formulated in very general terms, given that sixty years of Spain's presence in the UN has implied hundreds of actions, speeches and declarations, proposals, the co-sponsorship of resolutions, support of specific actions, many multilateral diplomatic tasks, participation in activities and voting in the various organs of the UN. All of these activities-be they of greater or lesser relevance-reflect Spain's participation in and evolving commitment to the UN. This Organization, over the 70 years since its creation, has experienced many crises and difficulties, many moments of extreme weakness, many limit situations, many failures. Nonetheless, the UN has always shown the ability to overcome these situations, rising up and continuing to advance, from a multilateral perspective, towards the attainment of its great and universal aspirations. ${ }^{\text {. }}$

The first section of my study is of an introductory character, describing the general approach I have taken with this article. In this first section, I will tentatively divide Spain's participation and interaction with the UN into broad time periods (I). A second section will deal with the principal

\footnotetext{
* Professor of Public International Law at the University of Barcelona (Spain) and Vice-President of the United Nations Association of Spain. Email: xpons@ub.edu.

The United Nations Association of Spain (ANUE in Spanish) has published two works, one on the occasion of the 5oth anniversary of Spain's admission into the UN and one on its 6oth, both involving the collaboration of the Ministry of Foreign Affairs and Cooperation (MAEC in Spanish). In these books, with the participation of a large group of professors, diplomats and United Nations officials, analysed various aspects of the UN's activity together with the main elements of Spain's presence in the UN. Both works also feature a useful and interesting appendix with data and statistics on the Spanish presence in the Organization, compiled by Ariadna Quintero Valderrama. These two works, which I had the honour of coordinating, and which will necessarily be cited over the course of this study, are X. Pons Rafols (coord.), España $y$ la ONU. 50 aniversario (Icaria/ANUE, Barcelona 2005, hereinafter España y la ONU); and X. Pons Rafols (dir.), Las Naciones Unidas desde España. 70 aniversario de las Naciones Unidas. 60 aniversario del ingreso de España en las Naciones Unidas (ANUE, Barcelona 2015, hereinafter Las Naciones Unidas desde España).
} 
political and legal issues that were present at the moment that Spain were admitted into the UN in 1955, after a decade during which the Franco regime was the object of sanctions and international marginalization (2). The following section, dealing with certain substantive issues regarding the actions of the UN and Spain, focuses on the UN and on the recognition and guarantee of human rights in Spain (3). Next, I analyse the role of the UN and Spain concerning the principle of selfdetermination of peoples, both in regards to Spanish colonial territories and their decolonization, as well as the permanent Spanish claim to Gibraltar before the UN (4). The following section will deal with the contributions of Spain to the UN's peacekeeping operations, and what this contribution has meant in terms of the modernization, internationalisation and the worldwide image of Spanish Armed Forces (5). In addition, I will discuss the participation of Spain in the mechanisms of pacific settlement of international disputes as well as the codification and progressive development of International Law, and its incorporation into the system of Spanish law (6). Finally, I will briefly analyse some of the most important Spanish initiatives and contributions, such as those relating to the reform of the Security Council, the struggle against terrorism and the Alliance of Civilizations (7). Before finishing my study, I will present certain final remarks that will provide a synthesis of this general evaluation of Spain in the UN.

\section{GENERAL APPROACH AND PERIODS OF SPAIN'S PRESENCE IN THE UN}

In addition to its absolutely general character, the approach I propose is characterized by a double point of view of a bidirectional character. First, I highlight some of the principal contributions that Spain has made to the UN. Secondly, I will describe key aspects of what sixty years of UN membership has meant for the political, economic and social evolution of Spain, as part of an Organization that expresses - as nothing else does - the universal aspirations to peace, development and human rights. Over the course of the following pages I will focus on this interaction: the impact of the UN, its principles and its work on Spain and in our country's evolution, as well as the impact of Spain's contribution to the United Nations.

Spain was admitted to the UN on December I4, 1955, which adds up to 60 years of membership in this international organization. ${ }^{2}$ Since then, both the UN as well as Spain have undergone enormous changes and evolution, the fruit of an intense process of historical evolution and of deep social, political and economic transformations. The changes in our world have been deep and broad: scientific and technological advances; economic growth; globalisation; new social orientations and changes in behaviour and ways of life; the Cold War and its end; the growth of the number of Member States due to decolonization and the dismemberment of a number of countries in central and eastern Europe; environmental risks; new international concerns; the progressive humanization of international society; and an enormous number of other changes of all types. Together, these influences have profoundly transformed our world over the past sixty years.

\footnotetext{
Resolution 995 (X), of the General Assembly, of December 14, 1955. The UN's admission procedure requires a prior recommendation by the Security Council, which was obtained through to Resolution I09 (1955), of December I4, I955.
} 
These are transformations that are reflected in the UN, and, in spectacular fashion, have been recognizable in the evolution of Spanish society starting in the 1950s. Over the course of these years Spain has passed from its long and dark night of Francoism to its current situation as a developed democratic State, a member of the European Union, fully incorporated into the international community and with a young and advanced society that is prepared for change. We cannot overlook, certainly, the profound economic crisis that is still affecting our country, and which has become intertwined with a very important political-institutional crisis. However, there is hope that these difficulties may give rise to new varieties of transformations and progress along a clear path of democratic advances.

For many anti-Francoist democrats the admission of Spain to the UN was a profound disappointment. After WWII the Allied powers did not complete their work of destroying Nazi and fascist regimes by intervening in Spain and bringing down the Franco regime. ${ }^{3}$ For these democrats, the UN, its constitutive document - the Charter of the UN- and especially the Universal Declaration of Human Rights of 1948 were an important reference point for democratic change and the recognition of human rights. However, these rights and this Charter contrasted with, were even absolutely incompatible with, the reality of the political regime existing at that moment in our country. The United Nations was the democratic ideal that they fought for, and for which they were unjustly repressed by the Francoist authorities. ${ }^{4}$ Despite Spain's admission to the UN, the Franco regime did not change even a hair of its authoritarian and antidemocratic character. This fact also shines a light on the fundamental political realities and the intrinsic weaknesses of the UN, which was designed to be an inter-State organization. Even though the UN has suffered from these intrinsic weaknesses and failures, in my view the UN was and continues to be a useful instrument that is both indispensable and well adapted for confronting the interconnected challenges of today's world. ${ }^{5}$

From this perspective, and taking into account the corresponding evolution of the political situation in Spain, I believe that three periods can be distinguished within the course of the sixty years that have passed since Spain joined the UN. The first twenty years, making for a first stage lasting from 1955 to 1975 , were passed under the Franco regime but lit the way to the regime's end upon the death of the dictator. During these years, Spain maintained a low profile, severely limited in its activities and marginal within the overall context of the UN. Spain was under the thumb of an authoritarian regime that would only slowly open itself to the outside world. Nonetheless, it maintained overseas colonies and received aid funds for development. During these years the regime

\footnotetext{
Cf., for example, F. Casares Potau, "Entre la decepción y la esperanza”, in España y la ONU, at 95-IO4.

4 I would also like to note the 1963 creation in Barcelona of the Association of Friends of the United Nations (currently the United Nations Association of Spain, ANUE). Cf., in this regard, M. Díez de Velasco Vallejo, "Mis años en la Asociación para las Naciones Unidas en España", in España y la ONU, at I05-I08; F. Ll. Cardona Castro, "La Asociación para las Naciones Unidas en España", España y la ONU, at 79-94; as well as the commemorative book Una trayectoria con futuro. 40 años de bistoria de la Asociación para las Naciones Unidas (A Path with a Future. 40 Years of History of the United Nations Association) (ANUE, Barcelona 200I).

With so much potential and capacity for adaptation to changes, I believe we can perfectly well speak of a "resilient" United Nations (cf. X. Pons Rafols, "Unas Naciones Unidas resilientes en su setenta aniversario", in Las Naciones Unidas desde España, at 85-IIo).
} 
restricted itself to seeing the UN as a kind of international conference, reducing it to a mere scenario for diplomatic activities that permitted it to maintain its doors open to the outside. ${ }^{6}$

These first twenty years of Spain's membership were also the years in which the UN began to multiply the international instruments it had available in the area of human rights. Spain kept a distance from these initiatives, which is hardly surprising given the regime's non-democratic character. Nonetheless, Spain was not the object of special denunciations in the UN, a situation resulting from the weakness of existing international instruments. The general direction of the UN, based initially on the principle of non-intervention in the internal affairs of the States - as stated in article 2.6 of the Charter - has changed in recent decades. This has been especially true since the end of the Cold War, and the UN now has a firm commitment to promoting and strengthening democracy, the rule of law and guarantees of human rights. A sample of this evolution came at the end of this stage, on the occasion of the last executions by the Franco regime, which took place on September 27, 1975. The UN and its General Secretary, together with other world leaders, such as Pope Paul VI and the then European Communities, inundated Franco with pleas for a pardon, pleas that were never answered.

For obvious reasons stemming from the principle of equitable geographic distribution, during this first stage Spain participated in both the General Assembly as well as some of the principal and subsidiary organs of the UN.7 For example, Spain was a non-permanent member of the Security Council for the two year period from 1969-1970, as well as of the Economic and Social Council for the three year periods from 1959-196I and from 1972-1975. This relatively low-profile participation as a member of the UN did not mesh with certain daring, inexplicable initiatives, such as that of seeking to be a non-permanent member of the Security Council the year after our country's admission. As Juan Antonio Yáñez-Barnuevo has noted, this first attempt on the part of Spain -in competition with Sweden - to obtain a seat on the Security Council ended, as was to be expected, in complete failure. ${ }^{8}$

A second stage in the relations between the UN and Spain, though of a much shorter duration, corresponds to the years of transition to democracy in our country, a moment during which Spain began to join various programs and conventions on human rights, both those of the UN as well as of the Council of Europe. 9 I believe that what most stands out in this brief but politically complex stage is precisely Spain's joining the UN treaties on human rights. It was on April 27, 1977 - even before the first democratic elections in our country, held on the I5th of June, 1977, and only a few days after

\footnotetext{
6 However, there are those in Spain that take an internationalist position, holding to a transformational vision of the future, and who value the UN as a forum and as an authentic instrument for cooperation amongst States (cf. J.A. Carrillo Salcedo, "Las Naciones Unidas: una interpretación de ciencia política", 17 Revista Española de Derecho Internacional (1964) $516-527)$.

7 Over these twenty years Spain repeatedly held one of the vice-presidencies of the General Assembly: in 1958, 1965, 1973 and 1974. In contrast, Spain has only served as the President of the General Assembly once. It was in 1985 that the Spanish ambassador, Jaime de Piniés, was elected to the presidency of the fortieth period of sessions of the General Assembly.

8 Cf. J.A. Yáñez-Barnuevo, "Setenta años de las Naciones Unidas: algunas reflexiones desde una vida en la diplomacia multilateral", in Las Naciones Unidas desde España, p. 63.

9 Furthermore, the Convention for the Protection of Human Rights and Fundamental Freedoms, signed in Rome on November 4, 1950, was only ratified by Spain on October 4, 1979, and recorded in the Official State Gazette (BOE) of October I0, 1979 .
} 
the legalization of the Communist Party - that Spain ratified the International Covenant on Civil and Political Rights and the International Covenant on Economic, Social and Cultural Rights of 1966. ${ }^{\text {I0 }}$ Along the same lines, on April I4, 1978 it ratified the Convention regarding the status of refugees and the protocol relating to that Statute. ${ }^{\text {II }} \mathrm{Up}$ to that moment Spain had only ratified the 1948 Convention on the Prevention and Punishment of the Crime of Genocide and the 1966 International Convention on the Elimination of All Forms of Racial Discrimination. ${ }^{\mathrm{I}}$

In this complex political and economic scenario, Spain received widespread support during the process of democratic transition, some provided by our neighbouring countries and some by the United States of America itself. ${ }^{13}$ However, the UN of those years did not have anything like its present-day commitment to aiding democratic political systems, to democratization and to free elections; this is a commitment that has been strengthened since the end of the Cold War. If more recent viewpoints had existed at that time, they would doubtless have contributed to strengthening the process of democratic transition as well as certain relevant aspects, such as transitional justice, that were in fact ignored during Spain's transition. Starting from these initial baby steps, our country's participation in the activities and programs of the UN has grown constantly.

The third stage, which was also the longest, covers more than half of Spain's sixty years as a member State of the UN; it corresponds to Spain's democratic and constitutional maturation. It stands out as a country that respects its international commitments, and is fully committed to an effective multiculturalism. Over this period, our country has been an ever more active participant in the functioning of the UN, having become a country that is internationally relevant - an indisputable intermediate power, as I see it-, active in providing international assistance to developing countries and a net contributor to the programs of the UN. ${ }^{14}$ It is practically impossible to synthesize the nearly forty years of Spain's participation in the UN as a democratic State. Still, one can get the gist through the annual speeches given during the general debate that opens the annual sessions of the General Assembly, speeches that reveal the itinerary of Spain's evolution as a fully committed member State. On many occasions these speeches have been the responsibility of the Minister of Foreign Affairs and Cooperation; however, in certain years, in particular those which have been especially relevant from the perspective of Spanish politics, the Heads of State, King Juan Carlos I and later King Felipe VI, have given the speeches. ${ }^{\text {I5 }}$

BOE of April 30, 1977 .

BOE of October 2I, 1978.

I2 To which it acceded on September 13, 1968 (BOE of February 8, 1969 and of May 10 1969, respectively).

13 With, for example, the results of the official visit of King Juan Carlos I to Washington in June of 1976, when the monarch gave a speech to the U.S. Congress.

${ }^{14}$ An increase in budgetary contributions followed on this evolution: one need only note that Spain's annual contribution to the UN for 1956 was I.I4\% of the total (in an Organization with 76 member states) while for the two year period of 2014-2015 it contributed $2.97 \%$ (in an Organization of 193 member states). This places our country at 9 th place as a contributor to the ordinary budget of the UN. For the budget for peacekeeping operations-which follows other criteria for funds-this $2.9 \%$ means that our country is the tenth largest contributor.

is Although the King's speeches are prepared by the Government. King Juan Carlos I spoke for the first time in the general debate of the General Assembly in 1986 (cf. the minutes of the session on September 22, 1986, Document A/41/PV.4). King Philip VI spoke for the first time as King only a few months after his coronation, on September 24, 2014 (cf. the minutes of the session in Document A/69/PV.6). 
To highlight just one institutional aspect of Spain's presence in the UN in this third, and longest, stage, our country has been elected as a non-permanent member of the Security Council on four other occasions, i.e. the two-year periods corresponding to 198I-1982, 1993-1994, 2003-2004 and, most recently - in a genuine success for Spanish diplomacy - for the current 2015-2016 period. ${ }^{16}$ This most recent elected term represents a responsibility and an important challenge for Spain's foreign policy (as on the other occasions, certainly). Nonetheless, Spain has an element that distinguishes it in terms of its internal politics. Its campaign for a new period as a non-permanent membership of the Security Council began in 2005 with a government of the Socialist Party; later, a government of the People's Party continued this UN campaign until the objective was attained. On the other hand, as on an earlier occasion (the two-year period of 2003-2004), general elections are being held while Spain holds a seat on the Council (elections planned for December 20, 2015). This could provoke a change in the governing party, or, at least, a rearrangement of the system of political parties in Spain. The principal political forces fully shared the goal of attaining Security Council membership, with the conviction that it would mean a greater relevance and presence for Spain in the international community. However, this presence involves a greater responsibility, which in turn implies a policy that is shared among the principal parties. Such a policy would mean that Spain becomes more proactive, maintaining a better-defined profile and a greater international presence.

Along these lines, I hold that Spain's participation in the UN - and now, as a non-permanent member of the Security Council- has been clearly guided by a "state policy" that enjoys a consensus among the principal political forces, both the party in government as well as those parties of the opposition that have the possibility of forming a government. This, however, is not what happened on the earlier occasion in which Spain was a non-permanent member of the Security Council, when in 2003 the government of the People's Party actively supported the American proposals to form a coalition that would accompany the U.S. in its war in $\mathrm{Iraq}^{17}$; the PP government also participated in the Azores summit. The war and occupation of Iraq - a genuine attack at the UN's waterline- also led to a schism in the Security Council, a deep division between the various Spanish political forces and a great clamour against the war on the part of public opinion. The first act of the new Socialist Party government, which won in the elections of March 14, 2004, was precisely to order the evacuation of Spanish troops that were participating in a secondary role, helping the U.S. in the war against, and occupation of, Iraq. In foreign policy, certainly, there's no such thing as a friend, only interests. I hold, nonetheless, that interests are and must always be the interests of the State as a whole

\footnotetext{
16 Analysing the Spanish presence in the Security Council into time periods also confirms, in a practical manner, that IO-I2 years constitute a reasonable and acceptable rotation interval, so that intermediate powers like Spain can form part of the Council. Turkey was defeated in its competition with Spain, since it had only been six years since its last election to the Council, and New Zealand's prudence was rewarded in the first voting, having waited twenty years for a new attempt (cf. the analysis of I. Molina, "España en el Consejo de Seguridad de la ONU 2015-2016: apuntes desde cuatro planos", Comentario Elcano 60/2014, Real Instituto Elcano, 2014).

17 The then-Minister of Foreign Affairs, Ana Palacios, participated actively in the famous meeting of the Security Council where the Secretary of State of the U.S. sought to demonstrate the existence of WMDs in Iraq (cf. the minutes of the February 4, 2003 session of the Security Council, Document S/PV.470I).
} 
and not just those of a particular political grouping. ${ }^{18}$ Looking beyond political differences, political actors should always keep in mind Spain's international role, its commitments to the international community and the confidence that Spain should merit among its members. Above all, such political actors must bear in mind the great objectives of peace, development and human rights that are clearly spelled out by the Charter of the UN, and by the Organization created through this Charter.

A final relevant aspect that I would like to mention, and which Spain will confront in 2016 as a non-permanent member of the Security Council, is the selection of the man or woman who will take Ban Ki-moon's place as General Secretary, since his second period in office will end on December 3I, 2016. The election for the post of Secretary General is carried out by the General Assembly following the recommendation of the Security Council, and in practice rotates among continents. There is also a consolidated practice that the person elected be able to complete two periods in office, of five years each. Spain already had the responsibility, as a non-permanent member of the Security Council, of campaigning for the election, for the first and only time up to now, of a Latin American as General Secretary: the Peruvian Javier Pérez de Cuéllar, who held the office from 1982 to 1991. The formal process of the election is not yet in progress, but various names are being mooted for the post. In particular, there are some female candidates from Eastern Europe: up to now no woman has served as General Secretary, nor has the post been occupied by anyone from this region.

\section{THE SPANISH QUESTION AND THE CONTEXT OF SPAIN'S ENTRY TO THE UN IN I955}

When the UN was created in 1945, Spain was under the thumb of an authoritarian regime that arose during the Spanish Civil War (1936-1939); the Franco regime had received military aid from the Nazi Germany of Hitler and the Fascist Italy of Mussolini. ${ }^{19}$ The regime did not participate directly in WWII -it declared, successively, its neutrality and non-belligerence- but it repaid the earlier military aid in a limited way by sending the Blue Division (División Azul). ${ }^{20}$ The characteristics of the regime and this collaboration with the Axis powers made it completely impossible for Spain to be invited to the San Francisco Conference where the Charter of the UN was adopted, or to participate in the newly-born United Nations. It was in this context - and in the framework of the different preparatory meetings for the UN itself that flowed together at the Conference of San Francisco- that Article Four of the Charter was written: to establish criteria for the admission of other States as members of the UN, with the basic condition that those new member States must be "peace-loving." ${ }^{21}$

\footnotetext{
I8 In a position contrary to this critical approach, cf. the memoirs of the then-permanent representative of Spain to the UN, I. Arias Llamas, "Mis vivencias en la ONU”, in España y la ONU, at 335-342.

19 It was in a climate of nationalist exaltation - and with Germanophile members in Franco's government who had supported Spain's entry into the second World War as part of the Axis- that General Franco met with Hitler in Hendaye (France) on October 23, 1940, and then with Mussolini in Bordighera (Italy) on February I2 of 194I.

${ }_{20}$ This division participated in combat alongside German forces on the Russian front, starting with the moment in which Germany declared war on the Soviet Union in June of 194I. It was withdrawn from the front in December 1943, when the predicted course of the war turned against Germany.

${ }_{21}$ Cf. in this regard, for example, J.A. Carrillo Salcedo, "La noción de Estados amantes de la paz, cincuenta años después de la entrada en vigor de la Carta de las Naciones Unidas”, I3 Anuario Hispano-Luso-Americano de Derecho Internacional (1997) 157-I80.
} 
States that had aided the Axis powers could not be considered as potential new Member States, so long as their formerly Axis-allied regimes remained in power. ${ }^{22}$ In August of 1945, at the Potsdam Conference - with the UN Charter already adopted but before its entrance into effect - the Allied powers clearly declared that they would not support the candidacy of the Spanish Government to form part of the UN.23

From that moment on, until 1955 , the "Spanish question" would be in the air at the UN, a question that implied international diplomatic sanctions and a diplomatic blockade against the Franco regime. ${ }^{24}$ The first condemnations of the Francoist regime took place during the first set of sessions of the General Assembly via Resolution 32 (I) of that Assembly on February 9, 1946, and followed by Resolutions 4 (1946), 7 (1946) and Io (1946) of the Security Council on April 29, June 26 and November 4, respectively. What was most relevant, nevertheless, was Resolution 39 (I) of the General Assembly, on December 12, 1946, entitled "Relations of Members of the UN with Spain", which recommended three types of sanctions against our country. In the first place, the government of Spain was excluded from all conferences and international organizations of the UN system. In second place, the Security Council would adopt any necessary measures if in "a reasonable amount of time a new Government is not formed that draws its legitimacy from the consensus of the governed". Finally, in third place, it was recommended that the Ambassadors or Ministers plenipotentiary who were accredited in Madrid should be immediately recalled.

Not only did the Security Council not agree on the adoption of measures against the Francoist regime, but in the next period of sessions the diplomatic blockade against that regime began to break down. ${ }^{25}$ The change in political scenarios in the context of the Cold War would soon decisively lessen the intensity of the international opposition to the Francoist regime and produce a progressive change of orientation. The Korean War, which was a military expression of the Cold War, in the end brought with it the adoption of Resolution 386 (V) by the General Assembly, on November 4, I950, which revoked the recommendation to withdraw Ambassadors and Ministers plenipotentiary from Madrid. The argument was that the establishment of diplomatic relations did not imply "any judgment on the national policies of that government." In addition, the recommendation that impeded Spanish participation in the international organisms established by the UN was revoked as well, with the argument that these were technical entities without any political character.

${ }^{22}$ According to the interpretation of the delegate of Mexico at the Conference of San Francisco, UNCIO, vol. VI, p. I27.

${ }_{23}$ Generally, especially regarding this process and what was known as the "Spanish Question", the most complete bibliographic references are: A. J. Lleonart y Amselem (dir.), España y ONU (6 vols. ed. CSIC, Madrid 1978-2002); F. Portero, Franco aislado. La cuestión española (1945-1950) (Aguilar, Madrid 1989); and I. Sánchez González, Diez años de soledad. España, la ONU y la dictadura franquista 1945-1955 (Universidad de Sevilla, Sevilla 2015).

24 Cf. A.J. Lleonart y Amsélem, "La admisión de España a la luz de los documentos oficiales de las Naciones Unidas", in España y la ONU, at 37-53.

${ }_{25}$ Resolution II4 (II), of the General Assembly, on November 17, 1947 -without reaffirming the measures adopted by the prior Resolution 39 (I) - limited itself to trusting that the Security Council would assume its responsibilities as set out in the Charter when it was judged that the situation demanded it, thus diminishing the political authority of Resolution 39 (I). 
This change in focus aided in the breakdown of isolation and Spain's progressive integration into international society. The first steps to integration into the UN system were taken in 1951, with Spain's entry into the World Meteorological Organization (WMO); the Food and Agriculture Organization (FAO) and the World Health Organization (WHO); Spain's re-entry into the Universal Postal Union (UPU) also took place in 1951, and was followed in 1952 by our country's admission into the United Nations Educational, Scientific and Cultural Organization (UNESCO). ${ }^{26}$ These incorporations, genuine precursors to full integration in the UN, were also accompanied by an important change in the attitude of the Allies, in particular the U.S. The new circumstances on the international stage resulted in the United States awarding the first financial credits to Spain-even though it remained outside the Marshall Plan - accompanied by the first visits of U.S. authorities. All of this had the objective of kick-starting negotiations and signing, on September 26 of 1953, the various executive agreements - of a political, financial and military nature-between Spain and the United States. ${ }^{27}$

A few weeks before the Agreements with the United States were signed, Spain's diplomacy won another triumph for the Francoist regime: the signing with Vatican City, on August 27 of 1953, of a Concordat between Spain and the Holy See that would regulate the relationship between the Catholic Church and the State. As is well known, the political process of opening the regime to the exterior world soon bore fruit in the Stabilization Plan of 1959, which led to the end of autarchy, to the adoption of development plans and to the "developism" of the I960s. The entry of Spain into the principal international organisms would have far-reaching effects, ${ }^{28}$ although Spain clearly had to remain at the sidelines of the European Community until a democratic transition had taken place. ${ }^{29}$ As before, the regime retained its authoritarian traits, despite its opening to the outside world..$^{\circ}$

Prior to the admission of Spain to the UN, for a number of years the latter had suffered an authentic paralysis in the admission of new Member States. This derived from political controversies between the respective sponsors of each bloc, as well as legal quarrels over the procedures and conditions for the admission of new States, which even involved two Advisory Opinions of the

26 Cf. the analysis of I. Sánchez González, "España ante los organismos técnicos de Naciones Unidas (1946-1953)", in A. Barrio Alonso; J. de Hoyos Puente; R. Saavedra Arias (coords.), Nuevos borizontes del pasado: culturas políticas, identidades y formas de representación (Universidad de Cantabria, Santander 20II) at $166 \mathrm{ff}$.

27 From a historical perspective regarding these accords, cf. A. Viñas, Los Pactos secretos de Franco con Estados Unidos. Bases, ayuda económica, recortes de soberanía (Grijalbo, Barcelona 198I).

${ }_{28}$ In 1958 Spain entered the International Monetary Fund (IMF) and the International Bank for Reconstruction and Development (IBRD), and in 1960 it joined two other organizations of the World Bank Group, namely the International Development Association (IDA) and the International Finance Corporation (IFC). Cf. concerning these integrations, F. Varela Parache; Manuel Varela Parache, "España y los Organismos Económicos Internacionales”, ICE No. 826 (2005) at I67I77.

29 The Preferential Agreement with the European Community remained unsigned until 1970, and it was only in 1977 that the long negotiations for EC membership began, negotiations that would not bear their fruit until 1985. Spain was admitted to the Organisation for European Economic Co-operation (OEEC) in 1959, and it would maintain this membership when the organism was changed into the Organisation for Economic Co-operation and Development (OECD) in 196r; in addition, Spain was admitted to the General Agreement on Trade and Tariffs (GATT) in 1963.

30 However, there were some who, from an internationalist perspective, demanded a full integration for Spain on the world stage, as well as participation in the trends of international society (cf. A. Pérez Voitúrez, "Las Leyes Fundamentales ante el Derecho Internacional”, 22 Revista Española de Derecho Internacional (1969) 248-279). 
International Court of Justice. ${ }^{3 \mathrm{I}}$ All of this resulted from confrontations between the two great antagonistic blocs originating from the Cold War itself. The negotiations to unblock the admissions process finally culminated in the so-called "package deal" articulated in Resolution 995 (X) of 1955, which permitted the admission of Spain and of another fifteen States. ${ }^{32}$ This process made clear the vocation of the UN to being a universal International Organization..$^{33}$

\section{THE UN AND THE PROMOTION AND GUARANTEE OF HUMAN RIGHTS IN SPAIN.}

As I have indicated before, the first stage of Spain's participation in the UN lasted until the end of the dictatorship, and coincides with the development within the UN of an ever more important system of international norms regarding human rights, with the establishment and perfecting of conventional and extra-conventional mechanisms for the protection of those rights. All of these instruments and mechanisms had and continue to have as their keystone the Universal Declaration of Human Rights, adopted in 1948 by the General Assembly, at a moment in which the UN still had the "Spanish question" on its agenda. ${ }^{34}$ At nearly seventy years after the signing of the Universal Declaration I believe I can justly affirm that this document has an undeniable ethical and legal value. The Declaration has contributed enormously to the idea that, while international society continues to be at base a matter between States, and even though International Law continues to have the sovereignty of States as its fundamental principle, human rights and the fundamental principle of human dignity are also being accepted as constitutional principles of today's international order.

It wasn't until 1977, during the process of democratic transition, that Spain began to adapt itself to the UN system of human rights with the ratification of the International Pacts of Civil and Political Rights and of Economic, Social and Cultural Rights. This ratification meant that the Committee of Human Rights would track Spain's progress in human and civil rights. The evaluation of the first Report on Spain, presented in 1978, highlighted a constructive focus on the part of the UN human

${ }^{31}$ Cf. in this regard, e.g. J. D. González Campos, "La admisión de España como miembro de la ONU: unas páginas de historia", in España y la ONU, at 2I-36, in particular, at 30-35. There is abundant bibliography concerning the conditions and procedure for admission to the UN, as well as regarding the political and legal process begun in 1955. However, the Revista Española de Derecho Internacional only realized Spain's admission in a general article by the French professor E. Giraud, "Admisión de nuevos miembros en las Naciones Unidas", 9 Revista Española de Derecho Internacional (I956) II-3I.

32 Together with Spain, a number of other countries were admitted to the UN as members in conformity with Resolution 995 (X): Albania, Austria, Bulgaria, Cambodia, Finland, Hungary, Ireland, Italy, Libya, Jordan, Nepal, Portugal, Laos, Romania and Sri Lanka. At the last moment, thanks to the political confrontation between the two blocs, Japan and Mongolia were taken off the list and were not admitted to the UN that year. With these 16 countries admitted, the UN reached 76 member States, which explains the important quantitative leap represented by this multiple admission at that time in history. Today there are 193 UN Member States.

33 Although Spain was admitted to the UN in 1955, thus relegating the "Spanish question" to the internal history of the $\mathrm{UN}$, it is nonetheless odd that the Charter of the UN-and the Statute of the International Court of Justice-were not officially published in Spain until 1990, with the publication of the Official State Gazette (BOE) containing the Unilateral Spanish Declaration of Acceptance of the Compulsory Jurisdiction of the International Court of Justice (BOE of November 16, 1990).

34 The Universal Declaration of Human Rights was approved by the General Assembly via Resolution 2I7 (III), of December IO, 1948. Concerning the Declaration, its adoption, content and relevance cf. X. Pons Rafols (ed.), La Declaración Universal de Derechos Humanos. Comentario artículo por artículo (Icaria/ANUE, Barcelona, I998), as well as J.A. Carrillo Salcedo, Dignidad frente a barbarie. La Declaración Universal de Derechos Humanos (Trotta, Madrid, 1999). 
rights organs, taking advantage of the democratizing process that had begun in our country with the adoption of the Constitution of 1978.35 Nevertheless, thirty years later, the renewed importance of Spain's democratic transition in the context of the recuperation of historical memory - and the demands of justice and truth on the part of the victims - have cast this approach into doubt. In recent years, various organs that protect human rights within the UN system have called attention to Spain, claiming that it has not adequately responded to the violations of human rights committed during the civil war and the ensuing Francoist dictatorship. ${ }^{36}$

During the third stage, with the Constitution of 1978 fully in effect, Spain became a fully democratic State characterised by the rule of law, respectful towards and guarantor of human rights and fundamental freedoms. In this context, and in a totally normalized manner, Spain signed onto almost all the UN treaties concerning human rights. ${ }^{37}$ This body of norms now forms part of internal Spanish law because of its reception through Article 96.I of the Constitution and, therefore-whether they have a self-executing character or not-they are now Spanish law and the judges and courts must guarantee their application. If the Universal Declaration of Human Rights has clearly influenced the body of international laws in the matter of human rights, it has also had an enormous influence on the internal laws of member States and, in a special way, on Spanish constitutional law. Indeed, the catalogue of human rights and fundamental freedoms that our Constitution incorporates clearly has its source in the Universal Declaration, which is expressly mentioned in Article I0.2 of the Constitution..$^{8}$ As a result, in addition to the internal application of the treaties concerning human rights, Spanish law recognizes the Universal Declaration and other international instruments in the matter of human rights as a reference for the application of the laws concerning the fundamental rights and freedoms that are recognized by the Constitution. 39

The incorporation of Spain as a party to the treaties concerning human rights also meant that our country became subject to the mechanisms of conventional control, through the committees established for certain of these treaties. This has meant for Spain that it must provide information via periodic reports and analyses, together with the corresponding publishing of observations on Spain on

35 Cf. the report on Spain in Document CCPR/C/4/Add.I, of September 8, 1978 and the Report of the Committee of Human Rights in the Document A/34/40 (Supplement no. 40).

${ }_{36}$ Considering it as damaging to the right to justice, the right to truth, the right to reparations and to guarantees of non-recurrence. This is what various Reports have stated in recent years (cf. for example, the Report of the Working Group on Enforced or Involuntary Disappearances. Addition. Mission to Spain, Document A/HRC/27/49/Add.I, of July 2, 20I4, and the Report of the Special Rapporteur for the promotion of truth, justice, reparation and guarantees of non-recurrence. Mission to Spain, Document A/HRC/27/56/Add.I 22 of July, 2014). An excellent analysis has been developed by R. Alija Fernández, "La transición española: una lectura desde la promoción y protección de los derechos humanos en la Organización de las Naciones Unidas", in Las Naciones Unidas desde España, at 619-634.

37 With the exception of the International Convention on the Protection of the Rights of All Migrant Workers and Members of Their Families, of December 18, 1990, which has still not been ratified by Spain.

38 Which sets out that "Provisions relating to the fundamental rights and liberties recognised by the Constitution shall be construed in conformity with the Universal Declaration of Human Rights and international treaties and agreements thereon ratified by Spain".

39 Cf., in general and among other authors, D.J. Liñán Nogueras, "La aplicación en España de los tratados relativos a derechos y libertades fundamentales", in A. Mangas Martín, Cuestiones prácticas de Derecho Internacional Público y cooperación jurídica internacional (Consejo General del Poder Judicial, Madrid 1994) 269-327. 
the part of the organs for human rights of the UN system..$^{\circ}$ Over the course of the years, this process has been highly positive for Spain, but there have also been certain negative aspects in the evaluations produced by the Committees concerning respect for and the evolution of human rights in Spain. Regarding the so-called special public procedures - such as extraconventional mechanisms for guaranteeing respect for human rights - I would like to emphasize that Spain was never the object of a special country-specific procedure, although it had been the object of thematic procedures, prompting various visits to our country by the special rapporteurs on human rights. ${ }^{4 \mathrm{I}}$

From an institutional point of view, the former Human Rights Commission ${ }^{42}$ only enjoyed the membership of Spain during three three-year periods, all from the democratic era in our country: 1984-86, 1988-1990 and 2000-2002. Ever since the creation of the Human Rights Council in 2006, which took over from the former Commission - although the Council is now an organ that depends directly on the General Assembly itself- Spain has attempted to become a member of the new intergovernmental organ on two occasions (2008 and 2010); it achieved its goal during the period from 20II-20I3 $3^{43}$. In addition to the procedures already indicated, this Human Rights Council has the responsibility of carrying out a periodic examination - carried out by the States themselves, that is, between peers - about the compliance of the States with their obligations and commitments in the area of human rights, in order to guarantee the universality and equality of treatment amongst all the States. This procedure - called the Universal Periodic Review (UPR), which could have much more "teeth" than what it currently has in practice- is one that all member States of the UN and Spain have to undergo. In Spain's case, it has had to pass this examination twice, first in May of 2010 and then in January of 2015.44

In sum, there is no doubt that Spain is today a democratic State that is respectful of human rights, to a great degree thanks to the effect that the UN system of human rights has had on internal law, as well as the European system of human rights. Focusing on just the UN system, it has been emphasized -in special procedures and in the observations of the various Committees regarding Spain's reports - that the pompous rhetoric of certain public declarations contrasts, at times, with the reality of weaknesses and identified risks that go back years. These problems have been correctly diagnosed by the various human rights organs of the UN, but it continues to be difficult to incorporate the recommendations that proceed from those organs. ${ }^{45}$

40 Cf., in general, above all, J. Bonet Pérez, "España ante los órganos de los tratados internacionales de derechos humanos de la ONU”, in Las Naciones Unidas desde España, at 585-602.

${ }_{4 \mathrm{r}}$ Cf. J. Saura Estapà, "España en el Consejo de Derechos Humanos: los mecanismos extraconvencionales de supervisión", in Las Naciones Unidas desde España, at 603-618.

${ }_{42}$ The organ for the promotion, stimulation and guarantee of human rights that was formerly dependent upon the Economic and Social Council.

43 Cf. the report on the merits of Spain as a prospective member of the UN Human Rights Council in Document A/64/704, of March 15, 2010.

44 Cf., in addition to the previously cited reference to J. Saura Estapà, "España en el Consejo de Derechos Humanos", what was noted in X. Pons Rafols, "El examen periódico universal en materia de derechos humanos y el primer examen sobre España del año 20I0”, II Agenda ONU (2009) 59-84.

45 To cite just a single example, on various occasions beginning in 2000 the Human Rights Committee has demanded that Spain recognize the right to a higher review of criminal cases (Article I4.5 of the Covenant on Civil and Political Rights). That is, the UN has denounced the fact that our legislation does not provide an effective procedure that would 
SPAIN, THE UN AND THE PRINCIPLE OF SELF-DETERMINATION OF PEOPLES.

The connection between Spain and the principle of self-determination of peoples must be understood from a double perspective. On the one hand, there is the good and the bad of the situation of the Spanish colonies in Africa, and their process of self-determination. On the other, Spain has mooted a standing claim, ever since its integration in the UN, to sovereignty over Gibraltar. In fact, the issue of decolonization was one of Spain's hot topics in its relations with the UN during the entirety of the first stage of its participation, especially regarding the Spanish colonial territories of Sidi Ifni, Equatorial Guinea and Western Sahara. ${ }^{46}$ This last territory was the object of an Advisory Opinion of the International Court of Justice in 1975. As is known, in the context of the weakness that General Franco's illness and death provoked, Spain abandoned its responsibilities to Western Sahara, in an ignominious act whose consequences for the Saharan people are still very much real.

Immediately after the admission of Spain, differences with certain other member States came to light, differences regarding the "legal condition" of certain African territories administered by Spain, but which were treated as overseas provinces. It was the same situation that Portugal found itself in but, in contrast with that country, Spain accepted collaboration with the UN in 1958, and eventually agreed to honour the conditions of Chapter XI of the Charter, a chapter dedicated to Non-SelfGoverning territories. ${ }^{47}$ Beginning in 1961, Spain began to provide information to the UN regarding the territories of Ifni, Fernando Póo, Rio Muni and Western (Spanish) Sahara. Beginning in 1965, the General Assembly adopted various resolutions, following the recommendations of the Special Committee (also called the Committee of 24) charged with examining the situation with a view to the application of the Declaration on the granting of independence to colonial countries and peoples, ${ }^{48}$ reaffirming the right of the people of those territories to self-determination. The administrating power was asked to aid in the exercise of the self-determination of peoples.

Further, in Equatorial Guinea a weak regime of autonomy was established beginning in 1963, with the fusion of Fernando Póo and Río Muni into a single entity, which was accepted by the Guineans through a referendum. The exhortations of the international community and the formation of

permit a higher court to review a lower court's condemnatory sentence, a requirement that has finally been made a part of our body of laws.

${ }^{46}$ Cf., in general, regarding Spanish decolonization from a historical perspective, the synthesis of J.B. Vilar Ramírez, "Franquismo y descolonización española en África", 30 Historia Contemporánea (2005) 129-158.

47 Distinguishing itself clearly from Portugal. This is why Resolution 1542 (XV) of the General Assembly, of December 15, 1960, looked favourably upon the commitment expressed by Spain. At the same time it demanded from Portugal an identical commitment regarding a list of territories that the General Assembly considered to be non-self-governing territories, following Chapter XI of the Charter.

${ }^{8}$ Cf. for example, regarding Equatorial Guinea, the Resolutions of the General Assembly numbered 2067 (XX), of December 16, 1965; 2230 (XXI), of December 20, 1966; and 2355 (XXII) of December 19, 1967. In regards to Ifni and Spanish Sahara, two territories that have been conditioned by the Moroccan claims that were expressly mentioned in the corresponding resolutions of the General Assembly (with the postscript "in consultation with the Government of Morocco"); cf. Resolutions 2072 (XX), of December 16, 1965; 2229 (XXI), of December 20, 1966; 2354 (XXII), of December 19, 1967; and 2428 (XXII), of December I8, I968. Jaime de Piniés, Spain's permanent representative before the UN between 1968 -1972 and between 1973-1985, published in 200I an exhaustive and complete analysis-with abundant detail-of the entire process of Spanish decolonization as it was lived in the debates and in the international diplomatic process of the UN (cf. J. De Piniés y Rubio, La descolonización española en las Naciones Unidas (Centro de Estudios Políticos y Constitucionales, Madrid 200I)). 
political parties in Equatorial Guinea led to the adoption of a constitution in 1968, together with presidential and parliamentary elections that led to a declaration of independence on October I2, 1968; Equatorial Guinea was immediately admitted as a new member State of the UN. ${ }^{49}$

In regards to Spain's other territories, it will suffice to note that when in 1956 France and Spainwith Spain being dragged along by France-conceded independence to Morocco, the decolonizing cycle was not by any means finished. Leaving aside the Moroccan claims to Ceuta and Melilla and other locations in Africa that were under Spanish sovereignty, the tensions with Morocco continued, first concerning Tarfaya and Ifni, and, at a second stage, Western Sahara. In the first phase, Morocco demanded the return of Tarfaya and Ifni, but the Spanish resistance to cede the southern zone of its former protectorate led to a war that was neither declared nor widely known, starting in October 1957 and ending in April 1958, which ended without a unclear result and with the signing of the Treaty of Angra de Cintra in the same year. With these accords Spain ceded to Morocco the southern zone of its former protectorate, an area that had not been ceded with Morocco's independence (Tarfaya), while retaining Ifni, even though its control of territory did not extend beyond the capital, Sidi Ifni. In the end, in accordance with the various Resolutions of the General Assembly I have mentioned, on June 30, 1969 Spain returned the territory of Sidi Ifni to Morocco via the Treaty of Fez, signed on January 4, 1969.

From that moment on, only Western Sahara would continue under Spanish administration, but with growing pressure from Morocco, which advertised its claims to the entire territory. The UN, for its part, continued to encourage Spain to decolonize the territory in consultation with the Governments of Morocco and Mauritania..$^{\circ}$ Various negotiations and various changes to Spanish and Moroccan foreign policy led to a situation of maximum tension in 1975. As a preliminary matter, as I have already noted, the General Assembly had requested an advisory opinion from the International Court of Justice, regarding two questions: "Was Western Sahara (Rio del Oro and Sakiet El Hamra) at the time of colonization by Spain a territory belonging to no one (terra nullius)?" and "What were the legal ties between this territory and the Kingdom of Morocco and the Mauritanian entity?" 5 In its advisory opinion, the Court declared first that Western Sahara was not terra nullius at the moment of its colonization and that the territory had at that moment certain legal links to both the Kingdom of Morocco and the Mauritanian entity, defined in the advisory opinion itself. Secondly, the Court declared that it did not recognize the existence of any legal links that would be, by their nature, capable of modifying the application of the principle of self-determination of peoples - as specified in Resolution 1514 (XV), of the General Assembly, of December 14, 1960- to the decolonization of Western Sahara.52 Even though a UN Mission — invited by the Spanish government - had visited the Sahara in May 1975, and Spain had fully accepted self-determination (although it was late to do so),

49 Via Resolution 2384 (XXIII) of the General Assembly, of November 12, 1968.

so Cf. the Resolutions of the General Assembly numbered 259I (XXIV), of December 16, 1969; $271 \mathrm{II}$ (XXV), of December I4, 1970; 2983 (XXVII), of December 14, 1972; 3162 (XXVIII), of December 14, 1973;

5I Resolution 3292 (XXIX), of the General Assembly, December I3, 1974.

52 Western Sabara, Advisory Opinion, ICJ Reports 1975, p. I2. Regarding the advisory opinion, cf. the analysis of J.A. Carrillo Salcedo, "Libre determinación de los pueblos e integridad territorial de los Estados en el Dictamen del Tribunal Internacional de Justicia sobre el Sáhara Occidental”, 29 Revista Española de Derecho Internacional (1976) 33-49. 
the very ambiguity of the advisory opinion was used by Morocco to maintain its claims to that territory. .3

In autumn of 1975 the Sahara question reached its most critical point, with the Green March under the impulse of Morocco- leading to the Tripartite Agreements of Madrid, of November I4, 1975. These accords were negotiated in very difficult internal circumstances for Spain (because of Franco's illness and his prolonged death throes), as well as a negative international situation (because of international disgust at the last executions under Francoism). By means of these Agreements, and paying no attention to the UN resolutions or Spain's own promises to the Saharan people, the Spanish government handed over the territory in question to Morocco and Mauritania, thus relinquishing its international responsibilities as the administrative power. ${ }^{54}$ The Spanish withdrawal was complete by February of 1976 and, since then, the Sahara has been involved in a long war for national liberation, as well as a prolonged United Nations Mission for the Referendum in Western Sabara (MINURSO), established with the yet unreached objective of guiding the process towards a referendum on self-determination.5 The situation continues to be genuinely blocked, and the Security Council has limited itself in recent years to renewing the MINURSO mandate, without any new initiatives or incorporating the dimension of human rights. Throughout these years Spain has been totally unable to adequately remedy the weakness and abandonment that resulted from the Madrid Agreements, even though it forms part-together with four of the five permanent members of the Security Council-of the Group of Friends of the Secretary General on the Sahara. As the administrative power for Western Sahara, Spain continues, in my opinion, to have an important responsibility towards the Sahauris. It must, in particular, aid in finding a solution that would unblock the process and facilitate, finally, the self-determination of Western Sahara. ${ }^{56}$

In the case of the permanent Spanish claim to Gibraltar within the framework of the UN, in 1946 the United Kingdom stated that it considers Gibraltar to be a non-self-governing territory. As a result, in conformity with Article 73 of the Charter, the UK has provided information to the UN in its role as Gibraltar's administrative power. In 1963, with Spain now a member State of the UN, and at the request of Cambodia and Bulgaria, the Committee for Decolonization - or Committee of the 24decided to study the issue and proceeded to include Gibraltar in the list of territories to be decolonized. In 1964 this Committee reached the so-called "Consensus of 1964" which, taking account of the unusual situation of Gibraltar, held that decolonization ought to proceed via Spanish-British

53 See, in general, the exhaustive work of F. Villar, El proceso de autodeterminación del Sábara, ed. Fernando Torres SA, Valencia 1982 and the memoirs of F. Villar y Ortiz de Urbina, "Diplomático en las Naciones Unidas", in España y la ONU, at 363-379, in particular in at 363-368.

54 In Resolution 3458 (XXX), of the General Assembly, of December 10, 1975, the request was again made that the administrative power meet its responsibilities by aiding in the exercise of the right to self-determination. The Madrid Agreements were noted, and all parties concerned were requested to respect the freely expressed aspirations of the Saharan people.

55 Established in Resolution 690 (1991), of the Security Council, of April 29, I991.

56 Concerning the Sahara conflict from the Spanish point of view, and from the perspective of International Law, cf. e.g. A. Badia Martí, X. Fernández Pons \& S. Carranza Förster (dirs.), La cuestión del Sáhara Occidental ante la Organización de las Naciones Unidas (Universidad Carlos III de Madrid, Madrid 1999) and J. Soroeta Liceras, El conflicto del Sáhara Occidental, reflejo de las contradicciones y carencias del Derecho Internacional (Servicio Editorial Universidad del País Vasco, Bilbao, 200I). 
negotiations, keeping in mind the interests of the inhabitants of the territory. This consensus was accepted by the General Assembly through Resolution 2070 (XX), of December 16, 1965, with the support of Spain and the UK.57 However, this latter country, rather than continue the negotiations, chose to follow its own path towards self-determination, organizing a referendum on Gibraltar in 1967, in which $99 \%$ of the voters expressed the desire to continue under British sovereignty.

Although the Resolutions of the General Assembly were positive for Spanish interests, the Resolution that was the most favourable for the Spanish position was 2353 (XXII), of December 19, 1967, wherein the General Assembly lamented the breakdown of negotiations and condemned the referendum. Further, in the preamble, it held that "any colonial situation which partially or completely destroys the national unity and territorial integrity of a country is incompatible with the purposes and principles of the Charter of the United Nations". For Spain the key point was that the territory is a colonial territory but, exceptionally, the right of self-determination did not apply due to the controversy over sovereignty, and its decolonization had to come about via negotiations between the two States..$^{8}$ Despite the fact that the Spanish position was widely supported within the UN itself, the UK, nevertheless, continued with its own policies, which would result in the promulgation in 1969 of a Constitution for Gibraltar, while Spain had taken the measure of closing the border fence as a means of exerting pressure on the UK.

In 1973 a new consensus was adopted in the General Assembly, demanding, once again, bilateral negotiations for the decolonization of Gibraltar, requiring the two governments to inform the Committee of 24 of the results of these negotiations. 59 Since 1974 the General Assembly has not adopted by vote any decision about Gibraltar, and has only adopted generic decisions. Furthermore, negotiations have been underway between Spain and the United Kingdom since 1980, a process that has gone through various stages, including the Process of Brussels, the Tripartite Forum for Dialogue and new instruments of local cooperation, with the UN limiting itself to taking note of these processes. In any case, the position maintained by the UN for more than 50 years constitutes an important asset for Spain, despite the fact that a definitive solution to the Gibraltar problem can only come about-as the General Assembly has repeatedly insisted-via negotiations between the two governments.

\section{THE PARTICIPATION OF SPAIN IN THE UN PEACEKEEPING OPERATIONS}

It is well known that the principal goal of the UN is the maintenance of international peace and security, and the other activities of the international organization must be somehow linked to that fundamental aim. In the final Document of the World Summit in 2005 this focus was reiterated with a inseparable triad of objectives: "that peace and security, development and human rights are the

57 Just as would occur with Resolution 223I (XXI) of the General Assembly, of December 20, 1966.

${ }^{8}$ Among the abundant bibliography about Spain and the Gibraltar issue, it is interesting to see how the problem has been viewed by the UN, as recounted in A. del Valle Galvez, "Gibraltar en las resoluciones y decisiones de la Asamblea General de la ONU, 1965-2015. Algunas valoraciones" in Las Naciones Unidas desde España, at 50I-517.

59 Cf. Resolutions 3163 (XXVIII), December 14, 1973 and 3286 (XXIX), of December 13, 1974, both passed by the General Assembly. 
pillars of the United Nations system and the foundations for collective security and well-being," and that these three elements "are interlinked and mutually reinforcing". ${ }^{60}$ Spain, as a member State of the UN, shares and participates fully in this holistic perspective, although all are aware of the centrality of peacekeeping and the privileged position of responsibility that corresponds to the Security Council. Thus, it should be valued just as Spain's participation as a non-permanent member of that Council has been valued. Whether or not Spain is actively working as a member of the Security Council, our country has supported the peacekeeping activities of the UN since its entry into the UN. This includes its financial contribution to the special account for peacekeeping operations; its presence on the Special Committee on Peacekeeping Operations between 1964-1970, between 1974-200I, and since 2006; its active and more recent participation in the Group of Friends of Mediation ${ }^{6 r}$; and, to note a final action, supporting the review process for Resolution 1325 (2000), of the Security Council, concerning Women, Peace and Security. This has led to the unanimous adoption of Resolution 224 (2015), of the Security Council, of October 13, 2015, an occasion when Spain was holding the rotating presidency of this Council.

What I would like to focus on now is our country's direct contributions of military and police forces, which have involved the provision of more than 140,000 men and women of the Armed Forces and of the Security Corps and Forces. ${ }^{62}$ This participation, over the course of more than 25 years, has also involved an important level of military and financial commitment by Spain and, above all, a notable cost in human lives at the service of the UN. Since 1989 nearly 200 members of our Armed Forces and Security Corps have died on UN missions, the majority of them victims of accidents. This participation has also turned Spain into a more relevant and influential actor, which in turn has also meant greater responsibility, such as that of being a non-permanent member of the Security Council.

But in addition to what these contributions, presence and influence have meant for our country generating a new reputation and image for Spain on the international scene- I believe another internal element of great importance should also be mentioned. I believe that the participation of the Spanish Armed Forces in international missions has contributed positively to the extraordinary improvement in the image of the Armed Forces among Spaniards. Three or four decades ago they were still seen as holdovers of Francoism. ${ }^{63}$ This improvement in the image of our Armed Forces has

60 Final Document of the World Summit 2005, Resolution 60/1, of the General Assembly, of September 15, 2005, para. 9.

${ }_{6}^{6}$ In a special way with the Spanish-Moroccan initiative for mediation in the Mediterranean, the first demonstration at the regional level of Resolution 65/285, of the General Assembly, of June 22, 2011, which exhorted the States to increase their capacity for mediation.

${ }_{62}$ For a general perspective on these issues, cf. I.C. Marrero Rocha, La participación de las Fuerzas Armadas españolas en misiones de paz (Plaza y Janés, Madrid, 2007); P.A. Fernández Sánchez, "La participación de España en las operaciones de mantenimiento de la paz de las Naciones Unidas: balance y perspectivas", in Las Naciones Unidas desde España, at 521-538; as well as F.J. Zorzo Ferrer, "Mis experiencias profesionales en las Naciones Unidas", in España y la ONU, at 283-315.

${ }_{63}$ In fact, there are those who hold that the Spanish participation in peacekeeping operations has marked an end to a "military transition" that lasted longer than the democratic transition in Spain [cf. C. Navajas Zubeldia, "El inicio de las Operaciones de la Paz como 'punto final' de la larga transición militar", in I. Sepúlveda (ed.), España en las operaciones internacionales de pacificación (Instituto Universitario Gutiérrez Mellado - UNED, Madrid 2009)]. Concerning public opinion about Spain's participation in peacekeeping missions cf. F. Arteaga, "Opinión pública española y misiones internacionales", in I. Sepúlveda (ed.), España en las operaciones internacionales ..., at I6I-I78. 
followed on their internationalization, as they share missions with military contingents from many other countries - seeing themselves as mirrored in the eyes of others- which has made them much more professional and modernized.

The first mission that featured Spanish boots on the ground was in 1988, with the sending, at the request of the General Secretary, of seven military observers to Angola to join UNAVEM I. ${ }^{64}$ This initial, limited participation would continue in 1989 - with the participation of a larger number of soldiers- in the United Nations Transition Assistance Group (UNTAG) established to assure the independence of Namibia. Immediately thereafter, also in 1989, Spain joined the United Nations Observer Group in Central America (ONUCA). In this latter mission, dealing as it did with countries of Central America, the Spanish presence had an obvious additional component, and it was also the first occasion on which an international mission of the UN was headed by a Spanish general. ${ }^{65}$ Beginning with these first missions Spain has participated in many others: our country has participated in nearly 30 UN peacekeeping missions. The mission that had the greatest Spanish participation was that of the United Nations Interim Force in Lebanon (UNIFIL). This mission also featured a Spanish general acting as Commander in Chief of the Mission and Special Representative of the General Secretary between 2010 and 2012. ${ }^{66}$ Apart from the Armed Forces, beginning in 1991 with the United Nations Observer Mission in El Salvador (ONUSAL), Spain's Civil Guard has also joined the military and police contingents on UN missions. In addition, the National Police Corps has carried out policing functions as well as police training on numerous missions. ${ }^{67}$

Various initiatives have arisen in order to reinforce the capacity of the UN for maintaining the peace. Given that the agreements foreseen in Article 43 of the Charter were never approved, these initiatives place military forces at the disposition of the UN in a stand-by posture. The purpose is to alleviate those weaknesses and overcome the voluntary, case-by-case makeup of the military contingents of these missions, thereby making the activation of a given mission more agile. With the end of the Cold War, and the new peace initiative that Secretary General Boutros Ghali proposed, ${ }^{68}$ the Security Council ended up supporting a system of reserve capacity that the member States could maintain in a state of full readiness, as a potential contribution to peacekeeping operations. Spain was one of the first member States of the UN to confirm their willingness to contribute those reserve capacities. In November of 1999 the UN and Spain formalized the corresponding Memorandum of

\footnotetext{
${ }^{64}$ United Nations Angola Verification Mission I, established in 1988 to verify the departure of Cuban troops from the territory of Angola.

${ }_{65}$ Cf. A. Quesada Gómez, "España en las operaciones de mantenimiento de la paz: Centroamérica y Nicaragua. ONUCA”, in España y la ONU, at 253-267.

${ }_{66}$ General Alberto Asarta Cuevas (for a discussion of his contribution, cf. A. Asarta Cuevas, "UNIFIL, trabajando por la paz en Oriente Medio", in Las Naciones Unidas desde España, at 547-559).

${ }_{67}$ Cf. M. López Corral, "La Guardia Civil en las Misiones Internacionales de Paz”, in I. Sepúlveda (ed.), España en las operaciones internacionales ..., at II9-I43, in particular $128 \mathrm{ff}$.

68 Basically in its Report An Agenda of Peace. Preventive diplomacy, the establishment of peace and maintaining peace, Document A/47/277-S/24III, of June 17, 1992.
} 
Understanding (MOU) about Spain's contributions to the system of agreements regarding United Nations standing reserve forces. ${ }^{69}$

Apart from Spain's financial contribution and, especially, the contribution of members of the Armed Forces and Security Corps and Forces to peacekeeping operations, I believe that our country's logistical contribution should also be noted. For instance, there is the construction and handing over to the UN of the UN Communications Centre - as a support base for peacekeeping operations and related operations of the UN- which, since 20II, has been functioning in Quart de Poblet, next to the Valencia airport..$^{\circ}$ On January 28, 2009, the UN and Spain signed an Agreement regarding the UN's use of facilities on Spanish territory for the provision of communications services to peacekeeping and related operations of the UN. These facilities were to act as a complementary centre to the one the UN already had in Brindisi. ${ }^{71}$

Finally, as a consequence of the political fracture that resulted from Spain's participation in the war and later occupation of Iraq, and the immediate decision of the socialist Government in 2004 to remove the Spanish troops, a reform of Spanish legislation on defence was mooted in 2005. The new legislation would place emphasis on the conditions and the authorization procedure required for the participation of Spain's Armed Forces in missions abroad. The Organic Law 5/2005, of November 17 , of National Defense (LODN), ${ }^{72}$ establishes, on the one hand, that any participation of the Spanish Armed Forces in international missions, or any increase in the military contingents already participating - whether it be a UN peacekeeping operation, or an operation under the aegis of NATO or the EU - there must be a prior authorization by the Congress of Deputies. In addition, out of respect for international law, the LODN establishes three cumulative conditions that we can term the condition of origin, the condition of finality and the condition of conformity with International Law. ${ }^{73}$

69 Cf. above all X. Pons Rafols, "La participación de España en el sistema de acuerdos de fuerzas de reserva para las operaciones de mantenimiento de la paz", 2 Agenda ONU (1999) I23-I64.

7o On a different topic, Spain's agreement with the World Food Programme (WFP) should be highlighted: it called for the establishment of a Distribution Centre for European humanitarian aid in Puerto de la Luz of Las Palmas, in Gran Canaria.

${ }^{71}$ BOE of December 2I, 2009.

72 BOE of November 18,2005 .

73 The following conditions were laid down in Article 19 of the Organic Law of National Defense (LODN in Spanish): the missions must either be expressly requested by the Government in whose territories they will be stationed; or they may be authorized by Resolutions of the UN Security Council; or they can be agreed upon by the international organizations that Spain is part of, in particular the European Union and the North Atlantic Treaty Organization (NATO), within the framework of their respective capacities. The missions must be defensive, humanitarian and have the aim of stabilization or keeping of the peace and they must be planned and ordered by the UN, the EU or NATO. Finally, the missions must be in accordance with the UN Charter and they may not contradict or harm the principles of international law that Spain has integrated into its own body of law, in conformity with article 96.I of the Constitution. Cf. a commentary on these requirements of the LODN from a legal perspective in X. Pons Rafols, "El Derecho Internacional, la Constitución española y la Ley Orgánica de la Defensa Nacional”, in H. Torroja Mateu (dir.) \& S. Güell Peris (coord.), Los retos de la seguridad y defensa en el nuevo contexto internacional (Publicaciones i Edicions UB, Barcelona 2007) 229-257. 
From a more legal perspective and, in particular, from the position of International Law, I believe that the presence and integration of Spain in the UN can be measured on three axes. First, there is an axis relating to participation in the great multilateral treaties adopted within the framework of the UN and, in particular, taking on the driving role in some of them. Secondly, there is an axis concerning Spain's litigiousness in the International Court of Justice, and the presence of Spanish judges on the benches of this principal judicial organ of the UN. These are aspects that have been analysed in our country by the man who was the Registrar of the Court between 1980 and 1986: the Spaniard Santiago Torres Bernárdez.74 Thirdly, there is the axis of the presence and contributions of Spanish citizens on the International Law Commission, a subsidiary organ of the General Assembly that has been charged with aiding the Assembly in the progressive development of International Law and its codification.

Regarding the first axis, over the years Spain has been integrating itself into the multilateral law scene, participating in the negotiations and ratification of the principal international treaties adopted in the framework of the UN. Aside from the human rights treaties I've already mentioned, Spain has followed the same path in many other areas, including diplomatic and consular relations, the law of the sea, the law of treaties and the entire sector of International Law related to the environment. All of these treaties have been integrated into our national law, establishing rights and obligations of International Law. Spain follows this law internationally, in virtue of the principle of good faith; in addition, Spain participates in the international negotiations that have led to the adoption of those treaties.

It is not just a question of Spain's participation - through its representatives in these international Conferences - in the negotiation, adoption and authentication of international multilateral treaties, later incorporating them into its national law. In addition, our country has played an especially relevant role in seeking consensus and in the facilitation of the negotiations between the States involved..$^{75}$ As an illustrative example of this work, there is the "consolidated" text that the Preparatory Committee of the Diplomatic Conference of Rome of 1988 prepared. In turn, this Conference adopted the Rome Statute, thereby establishing the International Criminal Court (ICC). This consolidated text was far from being fully agreed-upon, and the negotiations between the States participating in the Conference were key to its success, helping in the resolution of both the legal complications as well as certain political issues. This is why, both during the preparatory phase as well as in the negotiation process at the Diplomatic Conference, above and beyond the active presence of the NGOs, the so-called "like-minded countries" played a relevant role, and became a genuine driving force in drawing up the Rome Statute. Spain was clearly present in this group of countries, a majority of them Western, although certain African and Ibero-American countries and other regions were

74 Cf. S. Torres Bernárdez, "La contribución española al establecimiento y desarrollo del arreglo judicial de las controversias internacionales por la Corte Internacional de Justicia”, in España y la ONU, at 207-249.

75 For example, Spain's participation in the UN Conference on the Law of Treaties stood out, according to S. Torres Bernárdez, ibid. at 232. 
present. ${ }^{6}$ This Spanish aid to the creation of the ICC and, in general, universal criminal jurisdiction, was preceded by the active assistance of Spain - which was then a non-permanent member of the Security Council- with the creation of the ad hoc courts for the former Yugoslavia and for Rwanda. Regarding international litigiousness before the International Court of Justice - there was very little, in general terms - I would like to note, initially, that when Spain was admitted to the UN in 1955, it also acquired ipso facto - as specified in Article 93 of the Charter - the status of a participating State in the Statute of the Court. Shortly after its admission to the UN, Spain faced its first lawsuit before the Court. The lawsuit started with the issue of the Barcelona Traction Light and Power Company Limited, a Canadian company with Belgian capital that had been declared bankrupt by a court in Reus (Tarragona province), which ordered an embargo of its assets and those of its subsidiaries. New stocks of the subsidiaries were sold to a new company, Fuerzas Eléctricas de Cataluña (FECSA), which consequently ended up with total control of Barcelona Traction in Spain. In addition to the long internal legal process, a first Belgian lawsuit before the ICJ in 1958 was withdrawn by the Belgian government, in the hopes that negotiations between the two governments would prove fruitful. When those negotiations failed, Belgium presented a new request before the Court in 1962, this time regarding reparation for the damages suffered by the Belgian shareholders of the company. The ad hoc judge for this lawsuit, as designated by Spain, was an Uruguayan named Enrique C. Armand-Ugon. The Court dictated an initial judgment regarding preliminary exceptions, rejecting some of the exceptions presented by Spain..$^{77}$ Finally, in 1970 the Court dictated its judgment on the issue. ${ }^{78}$ In that decision, the Court, without entering in depth into the case, ruled that Belgium lacked the necessary ius standi for providing diplomatic protection to the Belgian shareholders of a Canadian company regarding the measures adopted against that company in Spain. International law, except in special circumstances that were not in play here, recognizes that only the Government of the company's nationality has the right to provide diplomatic protection. ${ }^{79}$

Another more recent issue was the lawsuit initiated in 1995, whereby Spain sued Canada over jurisdiction in the matter of fisheries. The suit denounced the relevant Canadian law and, in particular, the concrete measures adopted in the execution of that law on March 9, 1995. These measures, as applied in the case at hand, included the chase, boarding and confiscation on the high seas of a fishing vessel, the Estai, which was cruising under the flag of Spain, fishing Greenland halibut in the zone regulated by the North Atlantic Fisheries Organization (NAFO). In this case the Court did not enter into the deeper issues in play, given that its 1998 judgment declared that it did not have competence to emit a ruling concerning the case. The basis of this pronouncement resided in the content of the reserve formulated by Canada in its optional clause, declaring its acceptance of the compulsory jurisdiction of the Court: the controversies arising out of or concerning conservation and

${ }^{6}$ Cf. the commentary on the work of this group in J.A. Yáñez-Barnuevo, "La Conferencia de Roma y el Estatuto de la Corte Penal Internacional: balance y perspectivas", in F.J. Quel López, Creación de una jurisdicción penal internacional (Colección Escuela Diplomática № 4, AEPDIR, Madrid 2000) at 23.

7 Barcelona Traction, Light and Power Company, Limited, Preliminary Objections, Judgment, ICJ Reports 1964 , p. 6.

${ }_{78}$ Barcelona Traction, Light and Power Company, Limited, Judgment, ICJ Reports 1970, p. 3.

79 Cf. In regards to the case of Barcelona Traction, cf. the issue of 23 Revista Española de Derecho Internacional (1970), dedicated exclusively to the subject and to the judgment of the International Justice Court. 
management measures taken by Canada with respect to vessels fishing in the Northwest Atlantic Fisheries Organization's Regulatory Area were excluded from its competence, as was the enforcement of such measures. ${ }^{80}$

There was a third issue before the International Court of Justice, in which Spain was the subject of a lawsuit brought by Yugoslavia in 1999 against it and nine other States that were members of the North Altantic Treaty Organisation (NATO), for violation of the obligation to not use force; these NATO members were claimed to have bombed Yugoslavian territory in an operation stemming from the Kosovo conflict. The Court decided that in this case as well it was not competent to enter into the issues in depth, due to the formal reason that Spain, in accepting the compulsory jurisdiction of the Court, did so in regards to those controversies where the other part had also accepted the Court's jurisdiction, with at least twelve months of anticipation prior to the formulation of the lawsuit. In this case, Yugoslavia had recognized the compulsory jurisdiction of the Court three days before formulating the lawsuit against Spain and the other NATO Member States. ${ }^{{ }^{8}}$

In addition to the issues that Spain was involved in directly, I believe that we should emphasize Spanish contributions to other issues brought before the Court, especially in regards to two advisory opinions and the clear Spanish position of promoting respect for International Law. I refer, on the one hand, to the already-cited Advisory Opinion on Western Sahara, an issue for which Spain formulated a number of allegations, some of them handled by eminent specialists in International Law. ${ }^{82}$ On the other hand, I hold that we should emphasize both the written declaration as well as the oral declaration - both formulated by Spain - concerning the Advisory Opinion of 2oro, about the concordance of International Law with the unilateral declaration of independence by the provisional institutions of self-government in Kosovo. ${ }^{83}$

Regarding the presence of Spanish magistrates on the International Court of Justice, the initial issue to emphasize is that in Spain's sixty years as a UN member there has been only one occasion when a Spaniard has served for a full period of nine years as a judge of the Court. This was Federico de Castro y Bravo, who was a member of the Court during the years 1970-1979. ${ }^{84}$ Ad hoc judges have been designated for issues that Spain had been involved in. These judges include the Spanish jurist and former Registrar of the ICJ Santiago Torres Bernárdez, both for the issue of jurisdiction in the matter of fisheries (Spain v. Canada) and for the issue of the legality of the use of force (Yugoslavia v. Spain), although in both issues the Court eventually declared itself non-competent. Spanish ad hoc judges have been appointed for other processes in which Spain has not been a party, but only Federico de Castro occupied the position in the ICJ in accordance with its Statute. ${ }^{85}$ This adds up to a presence

8o Fisheries Jurisdiction (Spain v. Canada), Jurisdiction of the Court, Judgment, ICJ Reports 1998, p. 432. Concerning this issue, cf. also the articles in a monographic section of the 51 Revista Española de Derecho Internacional (1999) at 89-16I.

8r Legality of Use of Force (Yugoslavia v. Spain), Provisional Measures, Order of June 2, 1999, ICJ Reports 1999, p. 76r.

${ }^{82}$ For example, José M. Lacleta Muñoz, Santiago Martínez Caro, Fernando Arias-Salgado and Julio D. González Campos.

${ }_{83}$ Both declarations were reproduced in the 63 Revista Española de Derecho Internacional (201I) 199-272.

${ }^{8}$ Only one Spaniard served the former Permanent Court of International Justice as a judge: Rafael de Altamira Crevea, from 1922 to 1939, although the outbreak of World War II meant that he continued to serve until 1946.

${ }^{85}$ Concerning the election of Federico de Castro and his work as a judge of the ICJ cf. X. Pons Rafols, "Federico de Castro: único miembro español de la Corte Internacional de Justicia”, ro Agenda ONU (2009) 75-105. 
that, in my opinion, is clearly insufficient. Spain has sought to revert without attaining the designation of a Spaniard as judge, being unable to obtain an absolute majority of votes in the General Assembly and in the Security Counci ${ }^{86}$.

The first issue to emphasize about the International Law Commission (ILC) ${ }^{87}$ is that it is made up of persons of "recognized competence in international law", who are chosen by the General Assembly for a period of five years, with the possibility of renewal. These are people who have been designated as individuals and not as representatives of States. The requirements for selection involve maintaining an equitable geographical representation, as well as assuring that there are never two members of the same nationality serving at once. Even with these conditioning factors, I believe that the participation of Spaniards on the ILC has been unjustifiably reduced in comparison with other countries of the same regional group, or in comparison with other countries admitted to the UN at the same time that Spain was. Indeed, I claim that the present situation is absolutely unjustifiable, given the scientific level and skill of Spanish specialists in International Law. ${ }^{88}$ In these sixty years only three Spaniards have been elected as members of the ILC, and up to now none have had their terms renewed. These are Antonio de Luna García, who served from 1962 to $1966^{89}$; José Manuel Lacleta Muñoz, who was a member from 1982 to $1986^{\circ}$; and, finally, Concepción Escobar Hernández, who has been a member of the ILC since 20II. ${ }^{91}$ Further, neither Luna Garcia nor Lacleta Muñoz were designed special rapporteurs for the ILC about any of the various topics that Commission deal. Concepción Escobar, at least, is acting as a special rapporteur for the topic of "Immunity of State officials from foreign criminal jurisdiction" and so far has presented four Reports with proposals for articles..$^{22}$

\section{SOME INITIATIVES AND CONTRIBUTIONS THAT ARE LEGALLY OR POLITICALLY RELEVANT}

Spain's belonging to the UN or any other intergovernmental organization, as Javier Roldán has noted, "confers on it a power - variable and not without conditioning factors - over the functioning of that organization"93 and, in general, over its political orientations. As I indicated at the beginning of this study, my objective has merely been to write a summary, and over the course of the preceding pages I have presented various aspects of the Spanish contribution. We play a role and exercise an influence that must - since 1986 and, in particular, since 1992, with the creation of the European Union and the

\footnotetext{
86 In 2005, there was a possibility that Prof. Julio D. González Campos would be elected, but in the end he was not.

${ }_{87}$ The Statute of the International Law Commission was approved by Resolution 174 (II) of the General Assembly, of November 2I, 1947. Its initial makeup of 15 members was progressively expanded, until it reached the current level of 34 .

88 Cf. in this regard X. Pons Rafols, "España en la Comisión de Derecho Internacional: balance a los cincuenta años de su creación”, I Agenda ONU (1998) I49-I64.

89 Cf. E. Pérez Vera, "La labor del profesor de Luna como miembro de la Comisión de Derecho Internacional", 2I Revista Española de Derecho Internacional (1968) 208-226.

$9 \circ$ Cf. J.M. Lacleta Muñoz, "Las Naciones Unidas en mi vida profesional”, in España y la ONU, at 349-353.

9r Prof. Escobar was initially elected a member of the Commission on April 23, 20Ir, in order to occupy the vacant position produced by the death of Paula Escarameia, of Portuguese nationality. On November 17, 20II, Escobar was chosen as a member, along with the rest of the ILC, for the period 2012-2016.

92 Cf. the four Reports on this issue presented by the Special Rapporteur in Documents A/CN.4/654, A/CN.4/66I, A/CN.4/673 and A/CN.4/686, submitted to the Commission in 20I2, 20I3, 2014 and 2015 respectively.

93 Cf. J. Roldán Barbero, Las relaciones exteriores de España (Dykinson, Madrid 200I), at 96.
} 
pillar of Common Foreign and Security Policy - be employed in agreement and in coordination with the other members of the EU.94 In this last section I will mention three legal-political issues that I deem relevant: first, the proposals for the reform of the UN and in particular the reform of the Security Council; second, the fight against international terrorism; and third, the initiative that created the Alliance of Civilizations, taken up by the UN.

Over the years, Spain has supported a number of proposals for the reform of the UN, ${ }^{95}$ although it is well known that the process of reform has not advanced significantly: it always gets bogged down in the reform of the Security Council. One of the few reforms of the Charter that have been successful concerned the Security Council: its membership was increased from II States to 15 in $1963 .{ }^{96}$ As a result, the number of non-permanent members rose from 6 to Io, while the five permanent members were retained. The composition of the Security Council and the right to veto - restricted to the permanent members - were criticized right from the moment of creation of the UN. Today the current configuration has become obsolete and no longer reflects the developments experienced by the international community since 1945. Nobody denies that the Security Council's present-day composition is far from satisfying the demands of the rest of the current 193 UN Member States. In addition, for more than 20 years there has been a certain general consensus that it does indeed need reform, for instance by increasing it from 15 to 24 or 25 Member States, so that it would have a more equitable representation. Nonetheless, after long debates and negotiations, and despite an agreement about the diagnosis, there is still no concrete agreement about how the reform should take place.

A reform of the Council, which would imply reforming the Charter, requires an affirmative vote from two thirds of the UN members. For it to entry into force, however, whether achieved via the path of Article 108 or else the path of Article rog of the Charter, it must be ratified by two thirds of the Member States, including the five permanent members of the Security Council. There must therefore be a broad consensus among member States, as well as the commitment of the permanent members of the Security Council. Among the various proposals for the reform of the Security Council, there are different positions taken by groups of States, which follow from their specific interests or regional character.

Spain forms part of the group Uniting for Consensus ${ }^{97}$ that proposes an expansion to 25 or 26 members, but only in the category of non-permanent members; in addition, the time in office of the more relevant non-permanent members would be extended to more than the two years currently provided for. Under this proposal, the non-permanent member States of the Security Council would be eligible for immediate re-election; that is, they would be elected more frequently and for more time, thus granting a kind of semi-permanent membership, albeit without the right to veto. The group also

94 A coordination that is referred to expressly by Article 34 of the Treaty of the European Union.

95 Although it is from 1995, see X. Pons Rafols, A. Olesti Rayo \& H. Torroja Mateu, "La reforma de la Carta de las Naciones Unidas. Informe analítico de la práctica de la Organización”, in Jornadas sobre el cincuenta aniversario de las Naciones Unidas (Colección Escuela Diplomática, Madrid, 1995) 79-II5.

96 Via the reform that took place on the basis of Article 108 of the Charter, and laid out in Resolution I99I (XVIII), of the General Assembly, of December 17, 1963.

${ }_{97}$ Spain is in a group with II other countries: Argentina, Colombia, Costa Rica, Mexico, Italy, San Marino, Malta, Turkey, Pakistan, South Korea and Canada. 
supports the elimination of the veto, or at least a rule that restricts its use; further, it seeks a more equitable representation on the Council, with non-permanent members from Africa, Latin America, the Caribbean and Asia. While waiting for a reform to the Security Council along formal channels, Spain and the group Uniting for Consensus also seek to modify a number of aspects of the functioning of the Security Council, in order to make it more transparent and attentive to the concerns of the other member States. Thus, representation would be linked to efficacy, transparency, legitimacy and the responsibility of the Council. Another path is that of the Arria-Formula meetings, which would permit the participation in the Security Council of other persons not strictly representative of the member States, thereby achieving higher levels of openness and participation.

Spain is very sensitive to the need to struggle against international terrorism, having been affected by terrorist acts ever since the 1960s. It has constantly supported the actions of the UN and has fostered international cooperation in the fight against international terrorism, in both the General Assembly and in the Security Council. In the General Assembly, the topic became a concern beginning in the 1970 s, ${ }^{8}$ when it adopted a number of declarations for the elimination of international terrorism. ${ }^{99}$ In 2006 - with the support of Spain - the General Assembly adopted the important document "UN Global Counter-Terrorism Strategy". ${ }^{100}$ In the framework of this Strategy, Spain contributed actively to the funding of the Counter-Terrorism Implementation Task Force (CTITF) and, in particular, to the Working Group on Supporting and Highlighting Victims of Terrorism. For its part, the Security Council is also concerned about international terrorism, which has increased in an exponential manner beginning with the end of the Cold War ${ }^{\text {ror }}$ and, especially, with the attack on the Twin Towers in New York on September II, 200I. In response, the Council created a CounterTerrorism Committee, ${ }^{\text {I02 }}$ which gained new life in 2004 with the assistance of a Counter-Terrorism Committee Executive Directorate, ${ }^{103}$ which was initially occupied by a Spanish diplomat. ${ }^{104}$

When the brutal attacks took place in Madrid on March II, 2004, the Security Council responded forcefully the same day, approving a Resolution of condemnation, Resolution 1530 (2004), of March II, 2004, in which it expressed its "reinforced determination to combat all forms of terrorism, in accordance with its responsibilities under the Charter of the United Nations". Initially there were attempts to exploit the attacks for political gain, which meant that in the Resolution itself the attacks were initially laid at the feet of ETA. A few days on, the permanent representative of Spain at the UN brought a letter to the President of the Security Council noting that other lines of investigation had

98 Cf. for example, V. Abellán Honrubia, "El terrorismo internacional”, 28 Revista Española de Derecho Internacional (1975) $33-56$.

99 Such as the Declaration on Measures to Eliminate International Terrorism adopted in 1994 via Resolution 49/60, of the General Assembly, of December 9, 1994, and the complementary Declaration adopted in 1996 via Resolution 51/210, of December 17, 1996.

100 Resolution 60/288, of the General Assembly, of September 8, 2006.

ror For example, Resolution I267 (1999), of the Security Council, of December 15, 1999, which created Committee 1267, for supervising the application of international sanctions to the Taliban and Al Qaeda.

${ }_{102}$ Resolution 1373 (200I), of the Security Council, of September 28, 2001.

${ }^{103}$ Resolution 1535 (2004), of the Security Council, of March 26, 2004.

${ }^{104}$ The ambassador Javier Rupérez (cf. his approach to the topic in J. Rupérez, "La definición del terrorismo y las Naciones Unidas: una historia interminable", in Las Naciones Unidas desde España, at 247-262). 
been opened. Two weeks later another letter was submitted, concluding that the attacks had been committed by a radical Islamic group. ${ }^{\text {Ios }}$

The final perspective I would like to emphasize has to do with Spain's continued action against international terrorism, concerning the impetus that it has brought to its current role as a nonpermanent member of the Security Council. Thus, for example, in July of 2015 Spain convoked a special meeting of the Counter-Terrorism Committee of the Security Council, related to the "Stopping the flow of foreign terrorist fighters". It also continued with its work of supporting the victims of terrorism, in accordance with the High-Level Conference on Victims of Terrorism in 20I2, acting as the protagonist in drafting a Statute for the victims. To that end, under a Spanish presidency of the Security Council, an informal Arria-Formula meeting of the Council was held this past October 2I of 2015, with the participation of the victims of terrorism. Finally, I would like to note the still-nascent Hispano-Rumana initiative for creating an International Court to combat terrorism, an initiative that is currently the object of preliminary diplomatic conversations.

In order to finish this section, I turn briefly to the Spanish initiative named Alliance of Civilizations. This initiative was proposed in 2004 by the then-President of the Government, José Luis Rodríguez Zapatero, before the General Assembly. Its aim was to literally create an alliance of civilizations between the Western world and the Arab and Muslim world. ${ }^{106}$ The following year, the then-Secretary General Kofi Annan formally launched the Alliance of Civilizations as an initiative of the UN, with the sponsorship of Spain and Turkey; later, he also named a High Representative. The Alliance aims to foment understanding and cooperative relations among States and peoples, between cultures and religions; further, it seeks to counter the forces that fuel polarization and extremism. The General Assembly supported all these initiatives in $2009^{107}$ and, since then, the Alliance of Civilizations has continued its work with meetings of the Group of Friends of the Alliance, and with periodic Forums and Conferences. The Alliance has become more concrete with the development of numerous projects and initiatives related to youth, education, the communications media, migrations, intercultural dialogue and innovation.

\section{FINAL REMARKS}

As I indicated at the beginning of this article, my intention has been to lay out a general summary of what, for our country and for the UN itself, our sixty years of UN membership have meant. This panorama has necessarily been general; I assume responsibility for leaving out many other aspects of importance to the UN/Spain relationship, which could have been highlighted but were not. To have analysed all the many aspects of Spain's relationship the UN would have required an extensive analytic review, both of the enormous work of the UN as well as the diplomatic correspondence of

Ios Cf. the letters, respectively, in Document S/2004/204, of March 15, 2004 and in Document S/2004/269, of March 31, 2004 .

ro6 In his speech during the general debate of the forty-ninth period of sessions of the General Assembly (cf. the minutes of the session on September 2I, 2004, Document A/59/PV.4).

107 By means of Resolution 64/14, of the General Assembly, of November 10, 2009. 
Spain's permanent Mission to the UN. As I have already noted, a number of Spanish diplomats have prepared memoirs of this type with a focus on a specific period or matter. Nonetheless, given the nature of this contribution I have chosen to develop a broad, diachronic perspective that touches on the diverse aspects that have seemed most relevant to me. This perspective largely begins, albeit not exclusively, with the point of view of Public International Law.

My firm conviction is that the UN is a useful and valuable instrument which should be strengthened, although it must adapt itself to the interconnected dangers, needs and challenges facing international society in the 2Ist century. This will inevitably require the political will of the member States. Even with all the weaknesses, restrictions and contradictions that plague the UN, and the lights and shadows of Spanish participation - in particular the limitations of the first of the three stages I have delimited - I have no doubts about the extraordinary strengths of the UN, about the continued validity of its purposes and principles, or about Spain's firm commitment to the UN. In the second, and especially in the third stage that I have defined, Spain has committed itself intensely to international peace and security, with an emphasis on sustainable development and the promotion of human rights, the three essential pillars of the UN system. Spain has done this, in my judgment, out of a deep conviction that multilateralism - represented by the UN-constitutes the only possible path by which the international community can overcome its impotence and actively face the challenges of the contemporary world.

Spain is an important country, a mid-level power, with a certain political and economic clout on the international scene: today, our country enjoys a global presence. It also has a strong ability for promoting dialogue, an ability that is the result of both historical and cultural influences as well as the confidence and credibility that have been generated by its international actions and commitments. Spain is an influential actor at the UN, but this is a two-way influence. As I have emphasized in this study, it is precisely Spain's active participation in the UN that permits reviewing and correcting the occasional shadows that crop up in its political action or in its commitment to human rights. This is what Spain's relationship with the UN is like, in my judgment: an interactive relationship that enriches both actors. Our country has contributed, certainly, to influencing the present-day UN, but in return its integration into the UN has contributed decisively to turning Spain into a modern, democratic State characterized by the rule of law, conscious of its influence in the world and of its international commitments. 